\title{
Body-map storytelling: research experience report with theoretical contribution of Bourdieu
}

O mapa corporal narrado: relato de experiência de pesquisa com aporte teórico de Bourdieu El mapa corporal narrado: relato de experiencia de pesquisa con aporte teorico de Bourdieu

Juliana Alves Viana Matos ${ }^{1}$

Kênia Lara Silva ${ }^{1}$ (1)

Marie-Carmen Garcia²

1. Universidade Federal de Minas Gerais.

Belo Horizonte, MG, Brasil.

2. Université Toulouse III. Toulouse, Centre de Recherches Sciences Sociales Sports et Corps, France.
Corresponding author:

Kênia Lara Silva.

E-mail: kenialara17@gmail.com

Submitted on $12 / 22 / 2017$.

Accepted on 05/29/2018.

DOI: 10.1590/2177-9465-EAN-2017-0407

\section{Abstract}

Objective: To analyze the use of the body map storytelling method sustained by Bourdieu's critical theory. Method: We present the basis of the method and describe our application experience on research about bodily practices in the health promotion field. Results: The 18 participants shared their experiences starting from the design of the body and the inclusion of artistic elements. Based on the discussion of body and health it was possible to relate bodily practices to life conditions, and the social context of participants. Data suggest that the body manipulation legitimate the agents' bodies for conformation and social acceptance. The different hexis elaborate the bridge between the body and social conditions. Conclusion and implications for practice: The realization of the body map storytelling with Bourdieu's theory contribution allows the comprehension of sociological contents, essential to nursing and health research.

Keywords: Qualitative Research; Scientific Research; Social Theory; Methodology; Motor Activity.

\section{Resumo}

Objetivo: Analisar o uso do método de mapa corporal narrado sustentado pela teoria crítica de Bourdieu. Métodos: Descrevemos as bases do método e relatamos a experiência de aplicação em uma pesquisa sobre as práticas corporais no campo da promoção da saúde. Resultados: Os 18 participantes do estudo compartilharam as suas experiências partindo do delineamento do corpo e a inclusão de elementos artísticos. Baseado na discussão sobre corpo e a saúde, foi possível relacionar as práticas corporais às condições de vida e o contexto social dos participantes. Os achados indicam que a manipulação corporal legitima os corpos dos agentes para conformação e aceitação social. As diferentes hexis elaboram a ponte entre o corpo e as condições sociais. Conclusão e implicações para a prática: A realização do mapa corporal narrado com aporte teórico bourdieusiano permite a compreensão de conteúdos sociológicos, essencial às pesquisas em saúde e enfermagem.

Palavras-chave: Pesquisa Qualitativa; Pesquisa Científica; Metodologia; Teoria Social; Atividade Motora.

\section{Resumen}

Objetivo: Analizar la utilización del método de mapa corporal narrado sustentado por la teoría crítica de Bourdieu. Métodos: Describimos las bases del método y relatamos la experiencia de aplicación en una pesquisa sobre las prácticas corporales en el campo de la promoción de salud. Resultados: Los 18 participantes del estudio han compartido sus experiencias a partir de diseño del cuerpo y la inclusión de elementos artísticos. Basado en la discusión sobre el cuerpo y la salud, fue posible relacionar las prácticas corporales a las condiciones de vida, y el contexto social de los participantes. Los datos indican que la manipulación corporal legitima los cuerpos de los agentes para conformación y aceptación social. Las diferentes hexis forman el puente entre e cuerpo y las condiciones sociales. Conclusión e implicaciones para la práctica: La realización del mapa corporal narrado con aporte teórico de Bourdieu permite la comprensión de contenidos sociológicos, esencial à las pesquisas en salud y enfermería.

Palabras clave: Investigación Cualitativa; Investigación Científica; Metodología; Teoría Social; Actividad Motora. 


\section{INTRODUCTION}

In this paper we report the use of body-map storytelling (BMS) as a possibility for qualitative research. The commitment to new techniques of production and data analysis has been experimented in the field of Sciences and Health, trying to respond to the constant search for innovations.

In this sense, it is important that the incentive to new methods not only occur using technology but also as a possibility of paradigmatic rupture aiming at the integration between theory and method. ${ }^{1}$ However, only when establishing the dialogical relationship between them, seeking to explain the goal and interpret it is it possible to carry out scientific research. ${ }^{2}$ On the other hand, the lack of theories that support scientific research is a problem that confines its use as a technique, compromising its validity. ${ }^{3}$

A construction process is needed to overcome this limit. This process should consider the movement of constant articulation between contents of the theory postulated in the analyzed central phenomenon. ${ }^{4}$ Investigative assumptions and methods create a plot throughout the development of research, giving meaning to findings and interpretations of the authors.

Nevertheless, the growth in use of new methodologies is in line with the attempt to operationalize research using problematic and reflexive approaches. These more inclusive methodologies respect values, beliefs and habits; and are a way of re-meaning the knowledge about a certain phenomenon. ${ }^{5}$ In this way, it is possible to engage agents in the research process, allowing a more active and coherent participation in critical social theory. ${ }^{6}$

The main objective of this paper is to analyze the use of BMS supported by the critical social theory of Pierre Bourdieu. The relatively recent method was described by Gastaldo et al. (2012) and is documented in the text "Body-Map Storytelling as Research".7

The proposal was first described as a therapeutic technique used for women and men living with the HIV virus and/or AIDS. ${ }^{7,8}$ Subsequently, it was adapted as primary data generation method, used to engage participants in the reflection of everyday themes. ${ }^{7}$ It is a process of creating replicas of the life-size body of the participant's body using drawing, painting or other artistic techniques to represent aspects of everyday life. ${ }^{7}$

We justify the use of BMS in participatory methodological research in which the aim is to promote the expression of feelings, thoughts and ideas. This is to understand political and social problems. ${ }^{7}$ Thus, we seek in this and other studies, scientific devices and experiences with this technique, which encourage the use of visual methodologies as a way of providing participants' engagement. ${ }^{7,9-11}$

This is a partial result of a doctoral thesis in Nursing. We present the theoretical and methodological assumptions for the use of the BMS technique. The main objective of the thesis was to analyze corporal practices in the field of health promotion, supported by critical sociology. In seeking to ensure theoretical and methodological coherence, we chose BMS to capture body practices from the perspective of its participants.

\section{APPROACH TO THE CONCEPTS OF CRITICAL SOCIOLOGY}

The option for critical sociology is based on the attempt to separate the interiorized look to access an external position, analyzing the phenomenon through the look of its agent. ${ }^{12}$ Among possibilities, the contribution of Bourdieu's theory is an option for research developed in Health Sciences, mainly for dialoguing with other fields making work easier for researchers. Its use requires an active and systematic attitude of researchers, breaking with the empiricist passivity that proposes emptied theoretical constructions. ${ }^{1}$

We propose the use of Bourdieu's concepts of habitus and body hexis. ${ }^{1,13}$ Habitus is perhaps the most used concept in Bourdieu's work. Although, it is not easy to understand and bring to the context of research. Bourdieu presents the following idea for habitus:

[...] as a system of acquired schemas that functions at the practical level as categories of perception and appreciation, or as principles of classification and simultaneously as organizing principle of action, meant to construct the social agent in its truth as a practical operator of object construction. ${ }^{14: 26}$

When we refer to habitus, we talk about a kind of embedded structure that will be perceived in the microsocial field. ${ }^{14}$ The concept opposes the extreme theses of structuralism, which consider active subjects, however simple "epiphenomena of structure". 15:7 Thus, habitus breaks with the contradictions between individual and society; individual and collective; conscious and unconscious; interested and disinterested; and objective and subjective. ${ }^{14}$

Habitus makes it possible to legitimize the agent as a practical operator of the construction of the object. ${ }^{1}$ For Bourdieu "Habitus is this unifying and generalizing principle that retranslates the intrinsic and relational characteristics of a position in a univocal way of life, that is, in a univocal set of choices of people, goods and practices". ${ }^{14: 22}$ Transposing the collective and reaching the individual, we understand the body hexis, one of the dimensions of habitus ${ }^{16}$ "[...] which speaks immediately for the motor as a postural scheme that is both singular and systematic, since it is in solidarity with a whole system of techniques of the body and instruments and loaded with a myriad of meanings and social values". 17:19

The uses of bodies produced by social conditions conform to hexis. This established relationship with the body does not reduce it to physical image, since it is a subjective representation. ${ }^{13}$ However, practical experiences incorporate the structures of the social world and are reflected in the micro space of the body. ${ }^{13}$ Under this perspective, the relation with the body is being incorporated and the body hexis incorporates social norms. ${ }^{18}$ 
The way we behave and the different ways of expressing ourselves socially are part of each person's way of occupying social space. Thus, although perceived in the micro space, hexis is easily transposed to other spheres and helps to understand society. The subjective representation of bodies and more deeply of corporal hexis occurs through a system of social classification: that is, bodies occupy a social position proportional to their distribution of fundamental properties. ${ }^{13}$

\section{THE EXPERIENCE IN USING BODY-MAP STORYTELLING}

We will now present the report on the experience of using body-map storytelling. The objective of matrix research was to analyze two corporal practices in the context of health promotion: dance and regional capoeira ${ }^{a}$. The choice of these practices was preceded by participant observation in the Cultural Centers of the city of Belo Horizonte. Spaces were investigated regarding the activities developed, working hours and public served, and those that best met the objectives of research were listed.

To achieve the objectives of the study, participants were invited to share their stories and experiences with the body practice analyzed through BMS. The technique was performed by the participant, and the researcher led and acted as facilitator of the process, as described in the literature. ${ }^{7}$

In research, 18 people participated, nine representatives from each of the practices, which generated 18 BMS. Each participant developed BMS over three meetings. We emphasize that, with two participants, we needed to increase the number of meetings to finish work, since both liked to dedicate themselves to the artistic elements, thus demanding more time to finish the activity.

Thus, 58 meetings were held, which took place between December 2016 and May 2017. They were audio-recorded, then transcribed and, at the last session, the body maps were photographed. The average time of each meeting was one hour and five minutes. The meetings were conducted respecting the time of each participant. We understand that some issues may require further reflection, delicate issues sometimes demand a longer period before resuming to the roadmap, such as: family problems, personal loss or trauma. At the end of each meeting, participants were asked to visualize the body map and narrate what they were able to see, to recapitulate what was said and to weave their considerations about the activity performed.

The course suggested by the semi structured script started from the microscope of the body, developing its outline. The idea was that, throughout meetings, participants would synthesize experiences related to their corporal practice. Thus, the activity proposed at the first meeting consisted in reading the informed consent form (ICF) and presenting the activity, outlining the body contour and discussing the relationships between body practice, body and health. Participants were asked to choose a posture representative, for them, of the corporal practice performed. In the second meeting, participants' living conditions were worked out and, in the third meeting, the facilitating and hindering elements of the corporal practice.

Body-map storytelling allowed us to analyze: participants discourse, images produced with the technique, as well as their narratives. Data were submitted to sociological analysis, which began with a critical reading of them. This included the definition of categories according to the levels of social organization (micro, meso and macro), culminating with reflexive interpretation. ${ }^{19}$

We highlight that the technical norms established by the Resolution of the National Health Council, 466, of December 12, 2012 were complied with. After the relevant clarifications, all participants signed the ICF. Research project was approved by the Research Ethics Committee and is registered under Certificate of Presentation for Ethical Consideration 55687616.7.0000.5149.

\section{SOME RESULTS: PONDERING ABOUT THE USE OF THE NARRATED BODY MAP}

Body was the starting point for relating bodily practices and relationships between social conditions. The script had issues related to daily life, work, social relations and the use of social services and devices to explore different aspects of social life. Through this exercise, we seek to gather life conditions, social context and how the practice relates to everyday life. The product, including the final narrative, and the body map photograph are exemplified below (Figure 1).

The story is about a black Afro girl.

She really likes dancing.

And she feels free while dancing.

Dancing makes her body show what only hearts are feeling.

The symbol of health is thumbs up.

The symbol of dance is representative of her life.

Her body is also a little doll with open arms, a way of showing freedom.

And the symbol of dreams, that dancing for her is a dream. (Participant 16)

From the outline of the body, participants had the possibility to relate to the corporal practice performed by listing the postures that they like and are able to do or wish to perform. Capoeira participants represent the hand standing, an essential technique for advanced movements and requiring strength and balance (Figure 2). 
Figure 1. Complete body map of participant 16. Source: Research file, 2017.

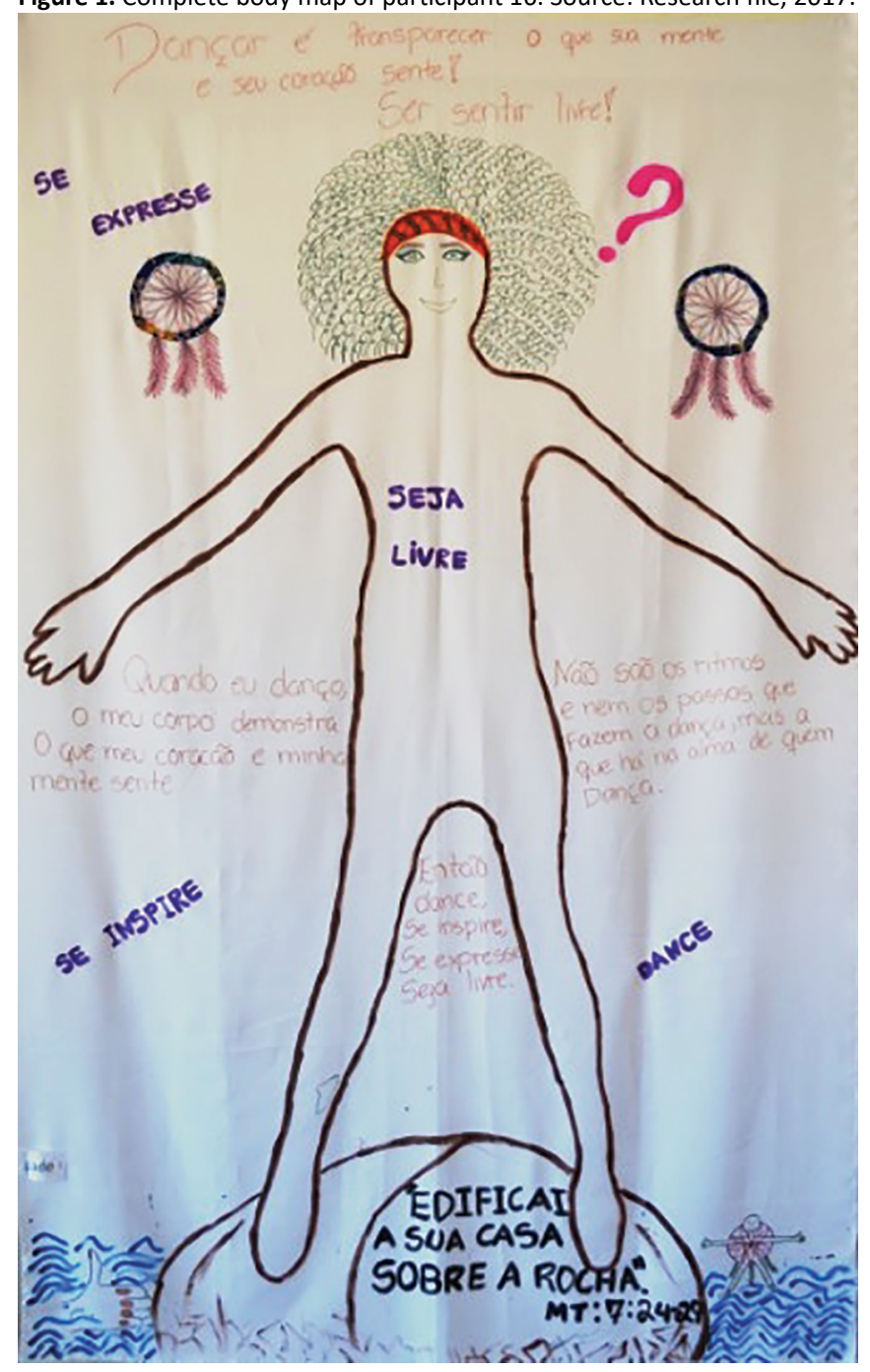

Figure 2. Body map of the participants indicating the hand standing. Source: Research file, 2017.

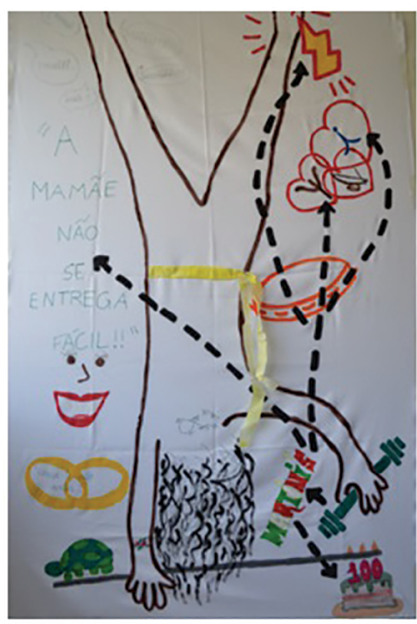

(a) Participant 5

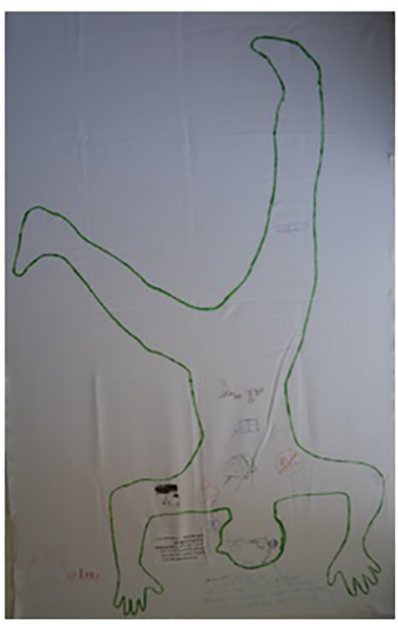

(b) Participant 2
Thus, the representation of the "I" begins and its relations with aspects related to daily life and as a practitioner of capoeira or dance. The choice of this initial position indicates who these participants are and what their identity is in the context of the analyzed practice. This is linked to the gestural and postural habits that are naturally internalized by accumulation and repetition within the body practices. ${ }^{20}$

Gesture, stretches and postures that are proper to the collective are an adjustment to social demands of a particular group. It is clear to participants that those positions will be recognized by their colleagues, but not necessarily by people who do not practice what they do.

In the context of corporal practices, experiences incorporate the structure of the social world, including social division of labor, and are reflected in the micro space of the body. We show that the body is not restricted to the individual sphere and contains subjective components that are susceptible to the investments of each subject. This reflection considers the frequency dedicated to the practice and other care related to its performance as diets, weight control, uniform and dressing. ${ }^{13}$

Body manipulation (whether of a provisional or permanent form) is understood as essential to the realization of the practices and the modeling of the body. Performing movements has as its central objective the legitimation of the body for conformation and social acceptance. It has revealed itself, for example, in the costumes of which we understand that it is important to participate in the capoeira rings wearing the abadá (specific clothing of capoeira) as well as, for dancers, to wear the costumes when presenting themselves publicly.

Life histories indicate the modifications of agents and how these bodies model themselves (or not) through the practice performed. In BMS, experiences were represented by structural elements of society and the conformations signed by different hexis, elaborating the bridge between body and social conditions. Examples include the overload of women's activities and their longing for good health.

Health was represented by participants mainly with foodrelated care (Figure 3). It is the way to represent health by the formula: food - exercise. In Figure 3a, participant 4 writes food she deems important for her health: "Natural juices, star fruit, acerola, apples with peanuts; water; rice, beans, tomatoes, peppers, cabbage, lettuce and beets", whereas participant 12 graphically represents the glass of water to talk about the importance of its consumption to health. At the same time, participants report difficulty in complying with the recommendations required to guarantee health in their hegemonic perspective, mainly due to the absence of time. This is a result of the excess of tasks related to routine work and employment, studies and family. This fact is evidenced by the drawing of the hourglass represented next to the water Figure $3 \mathrm{~b}$.

Among the different representations, the relationship between social division of labor between the female and male bodies was revealed. Body hexis reflects the role occupied by 
Figure 3. Details of the body map of two participants showing their relationship with health: through words (a), through water consumption (b). Source: Research file, 2017.

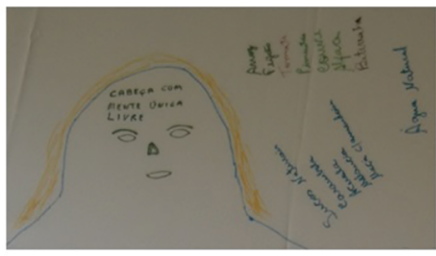

(a) Participant 4

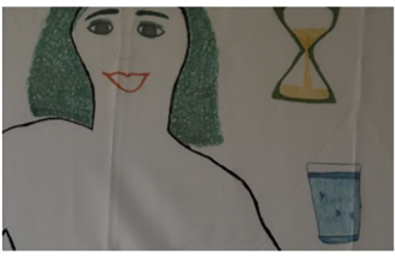

(b) Participant 12 women today (Figure 4): multiple working days; difficulty of caring for oneself before the priorities of family that are highlighted on the body maps. As shown in figure $4 \mathrm{a}$, participant 5 uses text to exemplify the demand of children "Mama... Mommyyy...Mom!!! Mooooom!!! Mommyyyy", whereas participant 7 (Figure 4b) chooses to symbolize all members of her family, people who depend directly on her care.

Figure 4. Details of the body map of two participants explaining the body hexis. Source: Research file, 2017.

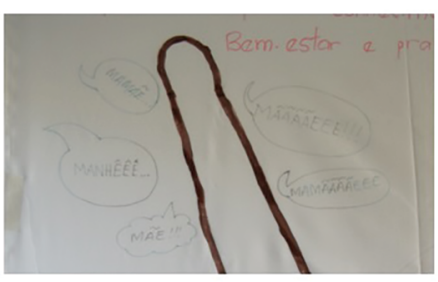

(a) Participant 5

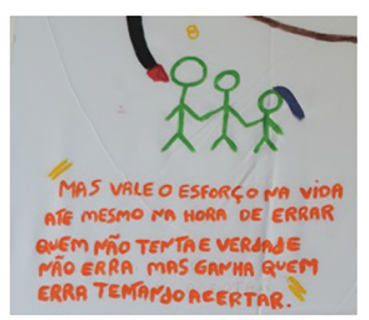

(b) Participant 7
The body is the product of a fabrication of its own with cultural determination. Nevertheless, BMS allows us to understand the agent, and preferences indicated by the participants during the meetings offer valuable clues about the habitus internalized by individuals. Some participants made complex connections and representations on maps, referring to the relations between the body and the social world as verified in Figure 2a. Others have shown their answers more literally, only through words, Figure $3 a$.

As for living conditions of participants, we noticed the desire to continue the corporal practice to which they dedicate themselves, For many, discovering this practice is reported as a pleasant moment in the daily life capable of promoting self-esteem and muscle transformation.

Oh, there are many things you get when you start dancing. First, an increase in your self-esteem; your perception of achieving what is being proposed is in stretching. [...] in the first contact with dance you already get them. You must be sensitive and ready to dive into that. Also, there's a muscle transformation I can tell you when you try dancing. (Participant 11)
However, except for those who have made capoeira their primary source of income, such as teachers and monitors, there is no guarantee that, in the future, this practice will be a part of their lives. Conflicts and difficulties sometimes make these plans uncertain:

Last year, I started an internship, but it was only part time and it did not disturb me at all in the beginning of capoeira classes. Then, I started to work [...] I had to stop my practice of capoeira. Not that I stopped at once, but since I left work late, when I got to class it was almost at the end. Then I was embarrassed to come in, I was really upset about it. (Participant 7)

[...] such as my everyday life, the rush, my dreams everything I do. Dance is meaningful to me in so many levels. It took me so far... It makes me forget or overcome difficulties. I wonder what benefits will I have in the future for practicing capoeira. (Participant 12)

In the narrative of participants 7 and 12 we can see the difficulty in reconciling time with the "rush" of daily life. This is indicative that the laborious routine and daily obligations can sometimes prevent their attendance and/or the dedication they wish to have for practicing capoeira. Our point is that habitus is also the product of social conditions, indicating that social structures contribute to the transformation and conservation of class structures. ${ }^{1}$ We have as an example the slogan of participant 5 "Mothers do not surrender easily". Here, we see how the narratives produced around the concepts of body habitus and hexis bring to light issues related to gender, work and living conditions.

In constructing BMS by producing discourses on bodily practices, participants drew reflections on a movement that characterizes participatory methodologies. We can affirm that we reached the BMS technique assumption: participants could perceive themselves as agents of a structured process, having the opportunity to capture a moment of participants lives along key elements of them. ${ }^{7}$

Corroborating with the findings of Gastaldo et al., ${ }^{7}$ we show that BMS allows participants to see themselves as protagonists, an integral and active part of the research process. Differently from the position assumed by some studies (that disposes their participants in a subordinate and dependent manner) the use of BMS allows a new rationality in the researcher-researched relationship. ${ }^{12}$ Thus, the innovation in the use of BMS lies in the propriety of the technique in favor of these interactions while research occurs with possibilities that the act of research produces interference in the life of agents. ${ }^{21}$

As pointed out in other studies,,$^{7,9-11}$ the challenges of using BMS refer to the personal and subjective character of the technique that may lead participants to think that they are in a 
therapeutic session. Although the researcher discourages them, some participants refer to the meetings as "consultations". Thus, we recommend that the conduct of the technique is always focused on meeting the objectives of research. Therefore, researchers can share the results of meetings with other researchers in a process that they participate and reflect on the implications created.

\section{CONCLUSIONS}

The search for innovations and methodological references are emerging demands for data analysis. This helps to subsidize health research and assists the construction of instruments that make it possible to change the social determinations to which we are exposed. ${ }^{12}$ Qualitative research through BMS is capable of provoking reflection on agents and researchers. It provides a better understanding of the social conditions revealed in the plurality of structures indicated in their body maps.

We highlight the potential of the technique to generate image data that architect the relations between micro and macro, in a permanent action of reproduction of the habitus of life. Body-map storytelling represents a commitment to a counter-hegemonic methodology that contributes to the participation of agents and, at the same time, commits itself to scientific development. From its use, we could verify how the bodies are expressed, without reducing them to body image, but as an objective representation of the body produced in continuous interaction with the other. Certainly, the point is about understanding this body under the perspective of self-image of its agents and of its determination through the environment.

Performing BMS with the theoretical contribution of Bourdieusian concepts makes possible the enlargement of the look on the real body and the legitimized body, fruit of representations. Other techniques have limits to reach images with elements that allow analysis in this depth level. Thus, we argue that the use of new ways of researching in health and nursing can strengthen and broaden the understanding of the phenomena with which we deal in the generation of empirical knowledge.

\section{REFERENCES}

1. Bourdieu P. O Poder Simbólico. Rio de Janeiro: Bertand; 1989.

2. Gomes MHA, Silveira C. Sobre o uso de métodos qualitativos em Saúde Coletiva, ou a falta que faz uma teoria. Rev Saúde Pública [Internet]. 2012 Feb;46(1):160-5. Available from: http://www.scielo.br/ scielo.php?script=sci_arttext\&pid=S0034-89102012000100020

3. Creswell JW. Projeto de pesquisa: métodos qualitativo, quantitativo e misto. $2^{a}$ ed. Porto Alegre: Artmed; 2007.

4. Minayo MCS. Amostragem e saturação em pesquisa qualitativa: consensos e controvérsias. Rev Pesq Qualitat [Internet]. 2017 Apr;5(7):1-12. Available from: https://edisciplinas.usp.br/pluginfile. php/4111455/mod_resource/content/1/Minayosaturacao.pdf
5. Oliveira EB, Kestenberg CCF, Silva AV. Saúde mental e o ensino sobre drogas na graduação em enfermagem: as metodologias participativas. Esc Anna Nery [Internet]. 2007;11(4):722-7. Available from: http://www. scielo.br/scielo.php?pid=S1414-81452007000400027\&script=sci_ abstract\&tlng=pt

6. Creswell JW. Qualitative inquiry and research design: choosing among five approaches. 2nd ed. London: Sage Publications; 2007.

7. Gastaldo D, Magalhães L, Carrasco C, Davy C. Body-Map Storytelling as Research: Methodological considerations for telling the stories of undocumented workers through body mapping [Internet]. 2012 Available from: http://www.migrationhealth.ca/undocumented-workersontario/body-mapping

8. Orchard T, Smith T, Michelow W, Salters K, Hogg B. Imagining adherence: body mapping research with HIV-positive men and women in Canada. AIDS Res Hum Retroviruses [Internet]. 2014 Apr; [cited 2018 Apr 18]; 30(4):337-8. Available from: https://www.ncbi.nlm.nih. gov/pubmed/24697645

9. Murasaki AK, Galheigo SM. Juventude, homossexualidade e diversidade: um estudo sobre o processo de sair do armário usando mapas corporais. Cad Ter Ocup [Internet]. 2016;24(1):53-68. Available from: http://www.cadernosdeterapiaocupacional.ufscar.br/index.php/ cadernos/article/view/1264

10. Quijano AR, Vieira A. A experiência da dor lombar como condição crônica em mulheres trabalhadoras da cooperativa do assentamento rural "Filhos de Sepé". In: Atas 5ํㅡㄹ Congresso Ibero-Americano em Investigação Qualitativa. CIAIQ [Internet]; 2016 Jul 12-14; Porto, Portugal. p.1286-91. Available from: https://proceedings.ciaiq.org/index. php/ciaiq2016/article/view/885/869

11. Davy C, Magalhães LV, Mandich A, Galheigo SM. Aspectos da resiliência e da integração social de jovens refugiados: um estudo narrativo usando mapas corporais. Cad Ter Ocup [Internet]. 2014 Sep; [cited 2018 Apr 18]; 22(2):231-41. Available from: http://www. cadernosdeterapiaocupacional.ufscar.br/index.php/cadernos/article/ view/1063

12. Bourdieu P. Para uma sociologia da ciência. Lisboa: Edições 70; 2001.

13. Bourdieu P. Remarques provisoires sur la perception sociale du corps Actes Rech Sci Soc [Internet]. 1977 Apr;14:51-4. Available from: https:// www.persee.fr/doc/arss_0335-5322_1977_num_14_1_2554

14. Bourdieu P. Choses dites. Paris: Les Editions de Minuit; 1987.

15. Bourdieu P. Raisons pratiques. Sur la théorie de l'action. Paris: Seuil 1994.

16. Corcuff P. Pierre Bourdieu: les champs de la critique. In: Colloque organisé par la BPI Centre Pompidou à Paris; 2004 Apr 11; Paris, France. p. 273-4.

17. Montagner MA. Pierre Bourdieu, o corpo e a saúde: algumas possibilidades teóricas. Ciênc Saúde Colet [Internet]. $2006 \mathrm{Apr} /$ Jun;11(2):515-26. Available from: http://www.scielo.br/scielo. php?script=sci_arttext\&pid=S1413-81232006000200028

18. Mennesson C. Être une femme dans un sport "masculin": Modes de socialisation et construction des dispositions sexuees. Soc Contemp [Internet]. 2004;55(3):69-90. Available from: https://www.cairn.info/ revue-societes-contemporaines-2004-3-page-69.htm

19. Pires RP. Modelo teórico de análise sociológica. Sociol Prob Prát [Internet]. 2014;(74):31-50. Available from: https://journals.openedition. org/spp/1426

20. Garcia MC. Approche critique de l'observation de dispositions de genrées. SociologieS, La recherche en actes, Ethnographie du genre. [Internet]. 2015 May; 1-12. Available from: https://journals.openedition. org/sociologies/5102

21. Almeida JF, Pinto JM. Teoria e investigação empírica nas ciências sociais Anal Soc [Internet]. 1975;365-445. Available from: http://analisesocial. ics.ul.pt/documentos/1223912596D1IPA2iy3Nz710D5.pdf

\footnotetext{
a Capoeira is a cultural practice with Brazilian roots that combines several elements including dance, fighting, playing, and body rhythm.
} 